DOI: 10.31392/NPU-nc.series14.2019.27.09

УДК 378.016:78

Палаженко О. П., Фіськов Г. М.

\title{
Зміст музично-просвітницької діяльності студентів-магістрантів у мистецьких закладах вищої освіти
}

\begin{abstract}
Розглядається поняття виконавсько-просвітницької підготовки студентів-магістрантів мистецьких закладів вищої освіти, яка вимагає сформованих професійних ігрових навичок і умінь, включає елементи просвітницької діяльності. Для сучасної фахової підготовки магістранта важливого значення набуває органічна єдність виконання музичних творів та вербального спілкування зі слухацькою аудиторією. Він має навчитися володіти лекторською майстерністю і живим словом. До цього додамо вміння підготувати для різної аудиторії емоційно насичену і захоплену бесіду, знайти відповідний музичний матеріал, що в цілому може зацікавити слухача. У межах вищої музичної освіти можна виділити низку важливих функцій, притаманних сучасному магістранту-просвітнику: пізнавально-евристична, творчовідтворююча, організаторська, комунікативно-емоційна. Аналіз просвітницької діяльності дає можливість визначити зміст поняття виконавсько-просвітницькі уміння студентів-магістрантів як дидактично доцільні способи дій, котрі передбачають самостійне оволодіння музичним матеріалом на виконавському і вербальному рівнях з можливістю трансформації у музично-просвітницькій діяльності.

Ключові слова: просвітництво; музично-просвітницька діяльність; заклад вищої освіти; магістрант.
\end{abstract}

Постановка проблеми. Огляд наукової літератури показав, що в сучасних гуманітарних науках феномен просвітництва розглядається досить широко. Зазвичай його використовують у двох значеннях - як прогресивну течію епохи переходу від феодалізму до капіталізму і як дію, пов'язану з освітою. Закономірності його розвитку і функціональні характеристики за другим значенням розкриваються у багатьох працях і досліджуються за наступними напрямками: визначення характерних рис просвітництва в педагогічному процесі (В.Андрєєв, І.Зимняя, О.Леонтьєв, І. Сипченко, В.Петрушин та ін.); підготовка фахівців до культурнопросвітницької роботи (С.Громов, М.Серьогін).Вчені також трактують просвітницьку діяльність як основу лекторської практики музикознавця (С.Дуков), засіб розвитку ораторської майстерності (С.Ножин, Н.Бабіч), засіб художнього спілкування з учнівською аудиторією (Б. Асафьєа, Т. Жигінас, Д. Кабалевський, Л. Кожевнікова, І. Липа, О. Мельник, В. Шацька).

Також зауважимо, що деякі науковці трактують поняття «просвітництво» в контексті інформування і передачі знань, розрахованих на різнобічну аудиторію. Основним завданням такої просвітницької діяльності стає широке розповсюдження інформації стосовно досягнень культури. Зокрема в монографії Ю.С. Зубова «Бібліографія і художній розвиток особистості» подана загальна видова структура інформаційної діяльності. Вона розподілена на три групи: інформаційно-потребові види діяльності, що містять перцептивну, пізнавальну і ціннісноорієнтовну складові; інформаційно-репродуктивні - мистецько-виконавську, науковопросвітницьку і пропагандистську; інформаційно-відтворювальні - художньо-творчу, науково-дослідницьку i критико-публіцистичну діяльність [2]. Автор розглядає просвітництво як різновид інформаційної діяльності. За логікою його міркувань між поняттями «інформація» та «просвітництво» простежується певний зв'язок. Аби його виявити, досить подивитися у словники. Серед варіантів перекладу з латини слова informatio бачимо: «усвідомлення, просвітництво, а також освічувати, навчати». Таким чином, просвітництво включається у семантичне поле інформації. Стосовно останнього поняття у тлумачному словнику С. Ожогова і Н. Шведової воно визначається як «розповсюдження знань, освіта» [5]. Відповідно зв'язок між просвітництвом та інформацією простежується не тільки у тому, що перше поняття є частиною другого, але й у тому, що вони обидва мають безпосереднє відношення до освіти.

Мета публікації полягає у конкретизації поняття виконавсько-просвітницької підготовки студентів-магістрантів мистецьких закладів вищої освіти, яка вимагає не тільки 
сформованих професійних ігрових навичок і умінь, але й включає елементи просвітницької діяльності.

Виклад основного матеріалу. Для сучасної фахової підготовки магістранта ЗВО важливого значення набуває органічна єдність виконання музичних творів та вербального спілкування зі слухацькою аудиторією. Він має навчитися володіти лекторською майстерністю і живим словом. До цього додамо вміння підготувати для різної аудиторії емоційно насичену і захоплену бесіду, знайти відповідний музичний матеріал, що в цілому може зацікавити слухача.

В межах вищої музичної освіти можна виділити ряд важливих функцій, притаманних сучасному магістранту-просвітнику: пізнавально-евристична, творчо-відтворююча, організаторська, комунікативно-емоційна. Розкриваючи сутність і значення пізнавальноевристичної функції, Ю. Борєв зауважує: «Мистецтво є засобом просвітництва (передача досвіду, окремих фактів), а також освіти (формування навичок мислення, узагальнення, системи поглядів). Воно виступає «підручником життя», який читають навіть ті, хто не любить читати інші підручники. Пізнавальна інформація, яка знаходиться в мистецтві, $є$ величезною. Вона суттєво впливає на наші знання світу. Поєднуючи власний життєвий досвід 3 досвідом інших людей, мистецтво слугує засобом пізнання світу i самопізнанням особистості» $[1,124]$. Такої ж думки дотримується й В. Холопова. При цьому вона зауважує, що музичні твори можна пізнавати у різних ракурсах: історико-фактологічному, філософсько-світоглядному, етико-емоційному [9]. У даному контексті музичнопросвітницька діяльність стає фактором самоудосконалення педагога-музиканта, збагаченням його музичної культури.

Творчо-відтворююча функція націлена на розвиток творчого потенціалу виконавця, який забезпечується набутими фаховими знаннями; вона також формує переконання, якими регулюється соціальна позиція педагога. В даному випадку виконання виступає творчим процесом відтворення музичного твору різними виконавськими засобами. У психологічному відношенні воно $є$ досить складною діяльністю, змістом якої є робота над музичним твором в цілому - від ознайомлення, роботи над технікою (знаходження і удосконалення доцільних ігрових рухів) і до відтворення на концертному виступі. Складність цього довготривалого процесу зумовлена різними завданнями виконавця й, відповідно, різноманітністю психічних реакцій. Психологічну сутність інтерпретації влучно висловив відомий музикознавець О. Сєров: «Велика таємниця видатних виконавців полягає в тому, що вони силою свого таланту висвічують твір із середини, просвітлюють, вносять туди цілий світ відчуттів із власної душі» [7].

Організаторська функція спрямовується на створення під час інструментального навчання нових музично-просвітницьких проектів, вміння передбачити їх результативність $\mathrm{i}$ в разі необхідності коригувати власну діяльність. Організація просвітницької діяльності залежить від того, наскільки педагогом і студентом усвідомлені їі мета, цілі та завдання, як реалізуються вибрані форми і методи іï проведення. Мета $\epsilon$ ключовим фактором просвітницької діяльності, вона передбачає і спрямовує рух спільної праці викладача і студента для досягнення загального результату. Мета конкретизується в стратегічних, тактичних та оперативних планах освітнього, виховного й розвивального характеру, а завдання закономірно визначають усі наступні елементи педагогічного процесу - зміст, форми і методи просвітницької діяльності студента. На думку О. Щолокової, центральним компонентом просвітницької діяльності $\epsilon$ планування. Воно передбачає поетапну розумову діяльність, за якої відбувається усвідомлення майбутнього потрібного образу, забезпечується повнота рішень поставлених завдань і системність педагогічної роботи [10].

Комунікативно-емоційна функція спрямовується на встановлення довірливого контакту 3 аудиторією, вміння реагувати на різні непередбачені ситуації, створювати атмосферу зацікавленості. Розглядаючи цю проблему, музикознавець Є. Назайкінський у своїх дослідженнях наголошує, що не тільки сутність, а й будова музичного твору не можуть 
бути зрозумілими поза художньою комунікацією. Саме в ній, на думку науковця, реально відбувається процес виконання та сприйняття музичних творів [4].

Творче самовираження майбутніх педагогів у процесі інструментальної підготовки передбачає використання діалогічного спрямування навчання в режимі сумісної продуктивної діяльності педагога і студента. Формування культури діалогу стає однією 3 найважливіших складових фахової підготовки майбутнього музиканта. Така творча інтерпретаційна взаємодія в процесі виконавського самовираження може інтенсифікувати взаємодію із слухачами (студентами) в умовах майбутньої просвітницької діяльності.

Необхідно зазначити, що за часи свого існування просвітництво в галузі музичного мистецтва як соціальний феномен збагатилося значною кількістю різновидів. Їх можна ранжувати таким чином: за формою (бесіда, концерт-бесіда, концерт-диспут, концерт 3 коментарями); за жанрами (монографічний концерт, концерт за змішаними жанрами, музично-просвітницький салон, музично-літературна вітальня, музичний фестиваль); за музично-виконавським складом (сольні концерти - інструментальні, вокальні, камерні ансамблі, симфонічні або хорові концерти, фрагменти з опер у концертному виконанні); за об’ємом (міні-концерт, традиційний концерт, циклічний концерт);за тематикою (монотематичні, політематичні); за аудиторією (вік, професія, соціальний стан: діти, молодь, середній вік, літні люди, музиканти-професіонали, аматори). Оволодіння усіма цими різновидами вимагає досить тривалого часу.

Розглядаючи цю проблему, Н. Корихалова зазначає, що складність роботи за цими видами полягає у різному рівні музичної культури слухачів, тому вона справедливо підкреслює, що «для успішної пропаганди музичних знань, крім системності, необхідно чітко уявляти іiі адресата» [3, 262]. Науковець наголошує, що одним 3 найважливіших просвітницьких завдань $є$ залучення до мистецтва широкої публіки, створення постійної слухацької аудиторії з урахуванням іiі естетичних смаків. Відтак студентам-магістрантам під час формування просвітницьких умінь треба мати на увазі, що форми і види виконавськопросвітницької діяльності можуть відрізняться за об'ємом музичної та вербальної інформації, а також їх співвідношенням.

Об’єднуючою рисою представлених видів виконавсько-просвітницької роботи є відбір програми, котра має поєднуватися або певною темою або смисловим стрижнем.

Можливості мистецького проектування розкриваються в індивідуальній виконавській роботі, яка має потужній розвивальний потенціал. Це зумовлено тим, що в результаті осмислення та інтерпретації музичних творів поєднується авторський і виконавський задум. Внаслідок цього виникає своєрідний художній образ, в якому реалізується авторська думка. У зв'язку з цим варто наголосити на можливості інтенсифікації виконавського процесу на основі впровадження дослідницьких елементів з урахуванням принципів самостійності й зацікавленості, а також створення власної виконавської концепції.

Вперше поняття «виконавська концепція» в галузі інтерпретації музичного твору запровадив С. Рахманінов. У своєму інтерв'ю для журналістів (1910) композитор i виконавець визначив десять характерних ознак досконалої фортепіанної гри. Цьому поняттю він надав особливого, першорядного значення. С. Рахманінов висловився таким чином: «Починаючи вивчення нового твору, надзвичайно важливо зрозуміти його загальну концепцію, необхідно проникнути в основний задум композитора, сформувати правильне уявлення про твір як загальне ціле». [6].

Визначення композитором цього поняття виявилося надзвичайно плідним для подальшого його осмислення. Зокрема українська дослідниця О. Фекете розглядає виконавську (інтерпретаторську) концепцію як смислоутворювальну функцію музичного мислення та особистісного досвіду виконавця. Відповідно вона виділяе дві форми іiі існування - стабільну і мобільну. За переконанням дослідниці, стабільна форма пов'язана 3 початковим етапом осягнення твору, тобто етапом художньої комунікації «композитор виконавець». Цей етап спрямовується на формування власної виконавської концепції завдяки 
розкодуванню композиторського тексту. Якщо він проходить успішно, зазначає автор, то нотний текст музичного твору набуває стабільності, а його інтерпретація стає важливим компонентом виконавської концепції.

Другим етапом художньої комунікації дослідниця вважає мобільну форму виконавської концепції, яка проявляється у аспекті «виконавець - слухач» і віддзеркалює процес комунікації із слухачами у різних проявах концертної діяльності. В основі цієї форми лежить фактор звукотворення, який проявляється в конкретній виконавській діяльності [8].

Безумовно, таке розуміння цього феномена розкриває стратегію художнього мислення виконавця, його бажання найбільш повно розкрити композиторський задум і передати своє ставлення до твору. Результатом цієї діяльності стає підвищення рівня сформованості виконавських умінь, а також інтелектуальних можливостей студентів-магістрантів. Відповідна робота знаходить своє вираження у підготовці до концертних виступів та музично-просвітницької діяльності.

Отже, виконавська концепція означає і стратегію мислення виконавця, і систему зав'язків та структурних планів у творі, і прагнення представити аудиторії твір у вигляді цілісного оповідання як авторського задуму, що дозволяє скоординувати музичні уявлення виконавця, наповнити їх особистісними смислами. Виконавська концепція є квінтесенцією смислів музичного твору i виконує смислоутворювальну функцію музичного мислення та особистісного досвіду виконавця, яка здатна формувати свідомість, у результаті чого удосконалюються результати інтерпретаторської творчості.

Висновки. Для студентів-магістрантів мистецьких ЗВО надзвичайно важливим $\epsilon$ формування артистично-вольових якостей, спрямованих на здатність публічно виступати перед аудиторією 3 інтерпретацією музичних творів. Специфіка інструментальновиконавської підготовки студентів-магістрантів у тому й полягає, що вже на стадії опрацювання музичного твору вони повинні «бачити» перед собою тих слухачів, 3 якими будуть ділитися матеріалом. Таким чином, виконавсько-просвітницькі уміння студентівмагістрантів набуваються в результаті певних дій, що формуються в результаті багаторазового повторення. Вони необхідні для здійснення музичного просвітництва i характеризуються високим ступенем засвоєння. До таких умінь належать: підбір та необхідна дидактична обробка теоретичного матеріалу; досконале опрацювання музичного матеріалу у виконавській діяльності; сформовані ораторські уміння; розвинуті комунікативні уміння.

Аналіз просвітницької діяльності дає нам можливість визначити зміст поняття виконавсько-просвітницькі уміння студентів-магістрантів мистецьких 3ВО як дидактично доцільні способи дій, котрі передбачають самостійне оволодіння музичним матеріалом на виконавському i вербальному рівнях 3 можливістю його трансформації у музичнопросвітницькій діяльності.

\section{Література}

1. Борев Ю.Б. Эстетика: учебник. М.: Высшая школа, 2002. 511 с.

2. Зубов Ю.С. Библиография и художественное развитие личности. М.: Книга, 1979, 149 с.

3. Корыхалова Н.П. В общении с музыкой: статьи и рецензии разных лет. СПб.: Композитор. Санкт-Петербург, 2011. 392 с.

4. Назайкинский Е. В. Звуковой мир музыки. М.: Музыка, 1988. 254 с.

5. Ожегов С. И., Шведова Н. Ю. Толковый словарь русского языка - 4-е изд., дополненное. М.: Азбуковник, 1999. - 944 с.

6. Рахманинов С. Литературное наследие. Всесоюзное издательство «Советский композитор». M.: 1978. $168 \mathrm{c}$.

7. Серов А. Н. Избранные статьи, т.2 : Гос. музыкальное изд-во, М. - Л. 1994

8. Фекете О. В. Проблеми взаємодії мистецтва, педагогіки та теорії і практики освіти. 2012. Вип. 34. C. $103-111$

9. Холопова В.Н. Музыка как вид искусства. М. «Планета музыки», 2014, 320 с.

10. Щолокова О.П. Основи професійної художньо-естетичної підготовки майбутнього вчителя К.: I3MH, 1996. $170 \mathrm{c}$. 


\section{Про авторів:}

Палаженко Олег Петрович, к.П.н., доцент кафедри духових та ударних інструментів Інституту мистецтв Рівненського державного гуманітарного університету; ORCID: 0000-0002-6992-8929

Фіськов Геннадій Миколайович, заслужений діяч мистецтв України, старший викладач кафедри народних інструментів Інституту мистецтв Рівненського державного гуманітарного університету (Рівне, Україна); ORCID: 0000-0003-3972-6653

\section{Contents of musical and educational activities of master students in higher education institutions}

This publication discusses the notion of performing and educating undergraduate students of art institutions of higher education, which not only requires professional playing skills and abilities, but also includes elements of educational activities. Thus, for the modern professional preparation of the undergraduate student, organic unity of performance of musical works and verbal communication with the listening audience becomes essential. He or she should learn to be proficient in fluency and lively words. Add to this the ability to prepare emotionally rich and engaging conversations for different audiences, find appropriate music material that may interest the listener as a whole. Within the framework of higher music education, there are a number of important functions inherent in the modern master-educator: cognitiveheuristic, creatively-reproducing, organizational, communicative-emotional. Therefore, for the undergraduate students of art institutions of higher education it is extremely important to develop artistic and volitional qualities aimed at the ability to speak publicly to an audience with the interpretation of musical works. The specificity of the instrumental and performing training of the undergraduate students is that already at the stage of processing a piece of music, they must "see" in front of those listeners with whom they will share the material. Thus, performing and enlightening skills of undergraduate students are acquired as a result of certain actions formed as a result of repeated repetition. They are necessary for the realization of musical education and are characterized by a high degree of mastering. Such skills include: selection and necessary didactic processing of theoretical material; perfect processing of musical material in the performance activity; formed oratorical skills; developed communication skills. The analysis of educational activity gives us the opportunity to define the meaning of the concept of performing and educational skills of undergraduate students of arts ZVO as didactically expedient ways of action, which provide independent mastery of musical material at the performing and verbal levels with the possibility of its transformation into musical activity.

Keywords: education; musical and educational activities; institution higher education; undergraduate.

\section{References}

1. Borev Yu. (2002). Graduate School. Moscow : Muzyka [in Russian].

2. Zubov Yu. (1979). Bibliography and artistic development of personality. Moscow: Kniga [in Russian].

3. Koryhalova N. (2011). In communication with music: articles and reviews from different years. Sankt-Peterburg: Kompozitor [in Russian].

4. Nazajkinskij E. (1988). The sound world of music. Moscow : Muzyka [in Russian].

5. Ozhegov S. (1999). Explanatory dictionary of the Russian language. Moscow: Azbukovnik [in Russian].

6. Rahmaninov S. (1978). Literary heritage. Moscow : Sovetskij kompozitor [in Russian].

7. Serov A. (1994). Featured Articles. Moscow : Gos. muzykalnoe uzd-vo [in Russian].

8. Fekete O. (2012). Problems of interaction, pedagogy and theory and practice of practice. Kiyiv: Muzyka [in Ukrainian].

9. Holopova V. (2014). Music as a form of art. Moskva: Planeta muzyki [in Russian].

10. Sholokova O. (1996). Fundamentals of professional art-aesthetics training of a future teacher. Kyiv: IZMN [in Ukrainian].

About the authors:

Palazhenko Oleh Petrovych, Candidate of Pedagogy ( Ph.D.), Associate Professor at the Faculty of arts, Rivne State University of Humanities (Rivne, Ukraine); ORCID: 0000-0002-6992-8929

Fiskov Hennadiy Mykolaiovych, senior lecturer at the Faculty of arts, Rivne State University of Humanities (Rivne, Ukraine); ORCID: 0000-0003-3972-6653 